\title{
CARCASS COMPOSITION, SPERMATOGENESIS PROCESSES AND PATHOGENIC THREATS OF MALE MALLARD DUCKS (ANAS PLATYRHYNCHOS L.)
}

\author{
FLIS, M. ${ }^{1}-$ BRODZKI, P..$^{2 *}$ \\ ${ }^{1}$ Department of Animal Ethology and Wildlife Management, Faculty of Animal Sciences and \\ Bioeconomy, University of Life Sciences in Lublin, 20-950 Lublin, Poland
}

ORCID: 0000-0001-7429-3158

${ }^{2}$ Department of Andrology and Biotechnology of Reproduction, Faculty of Veterinary Medicine, University of Life Sciences in Lublin, 20-950 Lublin, Poland

\author{
*Corresponding autor \\ e-mail:wetdoc@interia.pl
}

(Received 23 ${ }^{\text {rd }}$ Sep 2019; accepted $8^{\text {th }}$ Jan 2020)

\begin{abstract}
The paper presents the characteristics of slaughter efficiency and chemical composition of carcasses, the course of spermatogenesis processes as well as epizootic and epidemiological threats of male mallard ducks (Anas platyrhynchos L.). Tests and analyses carried out indicate a high slaughter output of $64.5 \%$ and a decrease in body weight during the winter months and the subsequent turning period. Muscles of male crosses were characterized by high protein content (23.54-23.58\%) and low fat content $(0.65-0.84 \%)$. In addition, a high level of unsaturated fatty acids, including those in the C 20 group, and a favorable UFA to SFA ratio of 1.5 were found. Organoleptic and bacteriological evaluation showed the presence of intestinal parasites of the Hymenolepididae family and muscle parasites of the Sarcocystis genus, as well as E. coli and Staphylococcus aureus, which were mostly resistant to the antibiotics used. The assessment of the advancement of the spermatogenesis process during the reproductive season showed the correct development of reproductive capacity in drakes. In addition, it has been shown that fully developed sperm capable of fertilization is produced at the turn of March and April, despite the fact that pairing occurs much earlier. The described composition of fatty acids indicates high pro-health values of mallard meat. At the same time, the parasites and bacteria found indicate that mallard duck meat may pose a risk to human health, and therefore carcasses must be tested before being intended for consumption.
\end{abstract}

Keywords: mallard duck, body mass, venision, slaughter efficiency, natural selection, bacterial diseases, Lublin Upland

\section{Introduction}

Mallard duck (Anas platyrhynchos L.) is one of the most common species of wild duck in many European, Asian and North American countries. They are also the ancestor of most domestic duck breeds. Can also be found in Australia and New Zealand (Tracey et al., 2008; Söderquist, 2012). In the United States, breeding crosses settled hunting grounds for hunting (Smith and Rohwer, 1997). In Poland, the mallard is the most huntable species among the four huntable of wild ducks that can be hunted and has been one of the most important game birds for many years. Despite the continuing downward trend over the past decade, approximately 100,000 wild ducks are acquired annually, of which around 95\% are mallards (Książkiewicz, 2006; List of hunting reporting data, 2018). As the reason for the decline in the population, the most frequently mentioned are transformations in aquatic ecosystems and the related reproduction processes of these birds. Therefore, an important element of knowledge about the population is to learn the principles of natural selection during the mating 
season and the timeliness of its course. It is also important to learn about male spermatogenesis processes, which directly affect breeding success, and thus natural growth. Although climate change and improvement of habitat conditions affect the increase of duck weight and survival in winter, it is not known whether these changes cannot have a negative effect on the spermatogenesis process and reproduction rates of mallard ducks (Guillemain et al., 2010). Guillemain et al. (2013) reported that climate change may have an impact on the course of many population processes such as: migration distance, mortality rates as well as reproductive distribution and success. In addition, climate change significantly affects the shift towards the north of the optimal winter refuges, as well as earlier migrations to the southern areas. Climate change also leads to the impoverishment of habitat and hence breeding areas. Consequently, the described elements may affect the course of reproductive processes as well as the raising of chicks, and thus the complete reproductive success (Gaston et al., 2009).

Hunting is one of the areas of social activity that is quite important in terms of culture and recreation. In addition, they allow the regulation of the size of individual populations on the principles of sustainable development. By hunting, it is possible to regulate the population structures of individual species that affect reproduction and survival rates, while optimizing the functioning of the population (Borman and Mattson, 2012). Not without significance is the fact that high-quality meat is provided, commonly referred to as venison, which is characterized by both taste and health benefits. Despite the fact that the global production of poultry meat shows an upward trend, many consumers are looking for an alternative in terms of meat quality, hence there is an increasing interest in meat from wild animals, in particular from wild game (Hoffman and Wiklund, 2006; Górecka and Szmańko, 2010; Nuernberg et al., 2011; Siminska et al., 2011; Kasprzyk, 2013; Ljung et al., 2015; Żmijewski et al., 2018; Flis et al., 2019).

On average in Europe, in total meat production, venison accounts for a small percentage of 0.2-0.4\% (Siminska et al., 2011; Popczyk, 2012). According to research carried out in Sweden, venison consumption also depends on the social perception of hunting in a given region and is characterized by quite considerable variation. Nevertheless, only $2 \%$ of the total consumption of this type of meat comes from sales in shops, while the remaining consumption is conditioned by the fact of hunting or the purchase of it is related to social networks (Ljung et al., 2015).

Among game meat from game birds, pheasant meat definitely prevails, which has very high taste and dietary values (Kuźniacka et al., 2007; Biesiada-Drzazga et al., 2011; Kokoszyński et al., 2014; Flis et al., 2019), nevertheless meat from mallard ducks is most often considered a culinary delicacy, but it is most often consumed in hunters' environment. This is conditioned by its periodic supply related to the hunting season, as well as the limited accessibility resulting from meat trade regulations, and thus the lack of companies distributing this type of game (Bertolini et al., 2005; Nuernberg et al., 2011; Popczyk, 2012; Janiszewski et al., 2018).

In the nutritional aspect, a fairly important element is the fatty acid profile, in particular the share of polyunsaturated acids. Meat from wild birds is usually characterized by an increased share of these acids, mainly omega-3, which is why it is referred to as dietary and health-promoting. The taste characteristics, high digestibility and quality of meat deserve emphasis, which is also largely determined by the content of polyunsaturated acids - n-3 and n-6 PUFA in an appropriate proportion (Mishra et al., 1993; Cobos et al., 2000; Janiszewski et al., 2018; Flis et al., 2019). In addition, meat 
from wild ducks is a valuable source of iron, zinc, copper and manganese (Lorenzo et al., 2011).

At the same time, one of the consumers' concerns about the possibility of consuming venison is the fact related to the common opinion about the possibility of contracting diseases (Nagalska and Rejman, 2014; Kwiecińska et al., 2016). Avian influenza is mentioned as the most dangerous in the mallard, which is a migratory species (Gunnarsson et al., 2012; Wille et al., 2018), however, other viral or bacterial diseases and quite often parasitic diseases, as well as mycoses are also found (Betlejewska et al., 2002; Żbikowski et al., 2006; Haščík et al., 2010; Dynowska et al., 2013; Flis and Grela, 2018).

Despite the fact that when consuming meat derived from carcasses of small animals, as a rule no research is carried out in terms of epidemiological risk, organoleptic assessment of carcasses and internal organs is carried out during post-mortem inspection and preparation of meat for consumption.

The aim of the study was to evaluate the composition of the carcasses, their slaughter performance and the chemical composition of the pectoral muscles in the aspect of healthy properties of wild duck meat. In addition, bacteriological and macroscopic evaluation (presence of sarcocysts) of carcasses was aimed at determining a possible threat to human health. The aim was also to assess the correct development of male reproduction capacity of male mallard ducks during the breeding period in terms of climate change.

\section{Materials and metods}

\section{Material}

The materials for work were male mallard ducks obtained by hunting, in accordance with applicable law in the hunting season in Poland, from October to December 2017 years. In addition, with the consent of the Minister of the Environment (decision DL-III.6713.21.2017.JC), five drakes were shot per month in the period from January to April 2018 years, i.e. during the protection period, in order to determine possible changes in the winter and spring, when the birds are exposed to increased pressure of environmental factors, and furthermore a leking site is taking place. Thus, seven periods of one month were identified in which the material for research was obtained. In total, 35 subjects constituted the research material. Male mallard ducks were shot in water reservoirs (fish ponds, small ponds and rivers) in the south-western part of the Lublin region (Figure 1).

\section{Preparation of tests}

In each case, after obtaining the birds, they were cooled down. Then, after being transported to the laboratory, each of them was weighed. The next weighing was performed after decapitation of the head. The next step was to nibble and weigh the carcass without feathers and lower legs. Then the birds were gutted and weighed again. Weighing also included edible intestines (heart, liver and muscle stomach after cleansing of gastrointestinal content). Each weighing was carried out on a laboratory scale with an accuracy of 1 gram. The entrails were stored in a refrigerator at $4{ }^{\circ} \mathrm{C}$ for 24 hours, after which they were sent for bacteriological and parasitological tests. 


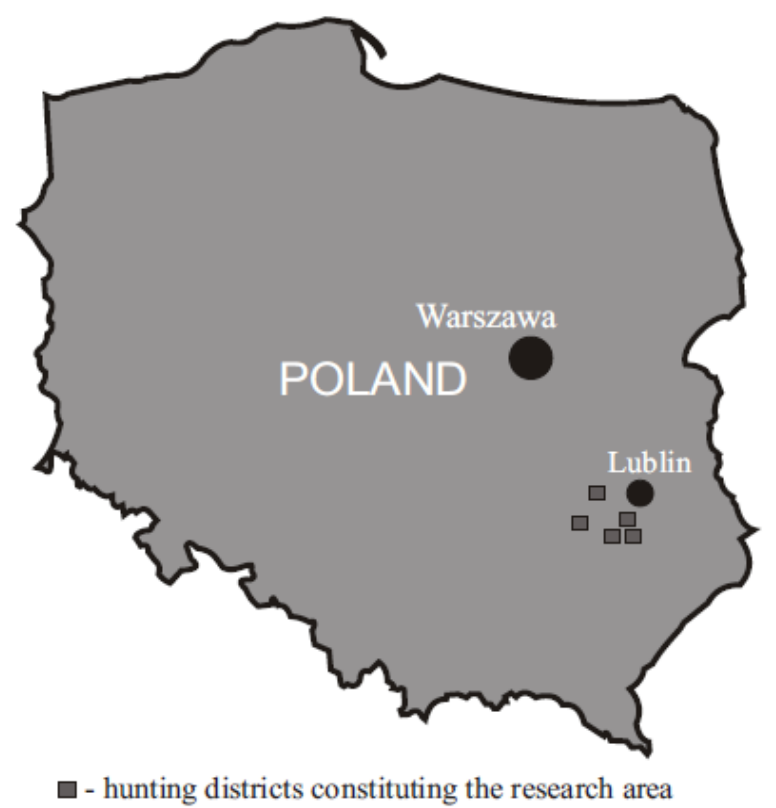

Figure 1. Location of the research area

Then the pectoral muscle ( $m$. pectoralis) of the birds was prepared, minced and stored one day at $4^{\circ} \mathrm{C}$, after which the crude fat content was determined according to the method of Folch et al. (1957). The fatty acid profile was determined by gas chromatography in the obtained fat. Fatty acid methyl esters were determined in a Varian CP 3800 gas chromatograph under the following assay conditions: CP WAX 52CB DF $0.25 \mathrm{UM}$ capillary column, $100 \mathrm{~m}$ long, carrier gas - helium, flow $1.4 \mathrm{ml} / \mathrm{min}$, column operating temperature $-120^{\circ} \mathrm{C}$ with a gradual increase of $2^{\circ} \mathrm{C} / \mathrm{min}$. up to $210^{\circ} \mathrm{C}$, determination time $-157 \mathrm{~min}$, dispenser temperature $-160^{\circ} \mathrm{C}$, detector temperature $-160^{\circ} \mathrm{C}$, supporting gases - hydrogen and air.

Also after evisceration, the testicles were dissected, which were stored in string bags for a period of 24 hours also at $4^{\circ} \mathrm{C}$, after which they were transferred to laboratory tests covering the course of spermatogenesis processes.

\section{Organoleptical, bacteriological research}

The macroscopic evaluation included the examination of each bird directly after shooting, plucking the carcass and skinning it. Its purpose was to capture possible lesions or occurrence of parasites.

Various multiplication and differentiation media were used to identify individual microbial species. The solid medium was agar with the addition of 5\% sheep blood to multiply aerobic microorganisms and possibly determine hemolysis. As a liquid medium, sugar broth was used to propagate aerobic bacteria. Other media, including Chapman, MacConkey, and Sabouard media were also used to identify possibly occurring organ mycoses. The cetrymid medium for the identification of Pseudomonas microorganisms and the D-coccosel medium for the identification of fecal bacteria were also used for the tests. Further identification of individual types of bacteria was carried out using bioMerieux API (Analytical Profile Index) biochemical tests. Media fertility control was carried out using standard strains. After determining the bacterial strain, the growth rate of bacterial flora was assessed using the criteria of fairly low (+), intesive 
$(++)$ and very intensive (+++). An analysis of the sensitivity of isolated bacterial strains to 7 commonly used antibiotics was also carried out. The analysis was performed using the diffusion-disk method (Kirby-Bauer) based on the diffusion of the antibiotic in the disk into the medium using the created concentration gradient. Based on the size of the bacterial inhibition zone, its sensitivity to a given antibiotic is determined by defining it as sensitive, moderately sensitive and resistant (Borowska et al., 2014). The sensitivity scale was determined on the basis of the tables of the "European Committee on Antimicrobial Susceptibility Testing" (EUCAST).

The following antibiotics were used for the analyzes in doses: Doxycycline DO30 -

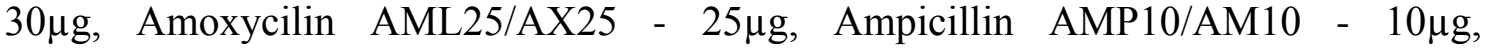

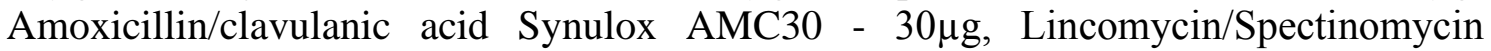

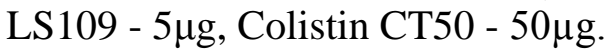

\section{Spermatogenesis process}

The prepared nuclei were weighed on a laboratory scale with an accuracy of 0.001 gram. Then microscopic preparations were made. The epididymis and testes were incised with a scalpel, followed by several imprint preparations on microscope slides. The preparations were dried, fixed and stained by several methods to obtain the bestquality microscopic image. The best preparations were obtained using the Hemacolor rapid staining method (Merck KGaA, Darmstadt, Germany). After preparation, the slides were evaluated on an Olympus CX4 light microscope with an attached Bassler A312 camera (Olympus Corporation, Japan) at 1000-fold magnification, under immersion. The image from the camera was read on a computer monitor, which facilitated the work and significantly improved the accuracy of the examination and allowed documentation of the preparations.

\section{Statistical analysis}

To determine the differences between the average values of the analyzed slaughter performance traits and testicles weight analyzed, between test periods, a one-way analysis of variance was performed. Considering equal sample sizes $(\mathrm{n}=5 /$ period), in order to verify the possible occurrence of differences between the means, calculations were made using the Newman Keuls test in Statistica 10.0. The impact of the study period was considered significant at a significance level of $\mathrm{P} \leq 0.05$. The value and significance of correlation coefficients between the weight of internal organs and the body weight and weight of duck carcasses were also calculated.

\section{Results}

\section{Body weight and characteristics of carcasses}

During the study period, despite slight fluctuations, weight loss occurred (Table 1). Between October and April this decrease was 10.3\% ( $y=-25.643 x+1316.9)$. This indicates a high impact of environmental factors on the body weight of birds, which is confirmed by the value of the determination coefficient of $\mathrm{R}^{2}=0.7303$. The average weight of drakes during the study period was 1214.3 grams. The carcass weight decrease was slightly larger and amounted to $11.4 \%$ ( $\mathrm{y}=-19.771 \mathrm{x}+865.03)$, which indicates the utilization of fat reserves in the winter period. The average carcass weight was 785.9 grams. 
Table 1. Weight characteristics $(g)$ carcasses of male mallard ducks during the testing period

\begin{tabular}{|c|c|c|c|c|c|c|c|c|c|c|c|c|c|c|}
\hline \multirow{3}{*}{ Item } & \multicolumn{14}{|c|}{ Period research } \\
\hline & \multicolumn{2}{|c|}{ I } & \multicolumn{2}{|l|}{ II } & \multicolumn{2}{|c|}{ III } & \multicolumn{2}{|c|}{ IV } & \multicolumn{2}{|c|}{$\mathbf{V}$} & \multicolumn{2}{|c|}{ VI } & \multicolumn{2}{|c|}{ VII } \\
\hline & $\mathrm{x}$ & SD & $\mathrm{x}$ & SD & $\mathrm{x}$ & SD & $\mathrm{x}$ & SD & $\mathrm{x}$ & SD & $\mathrm{x}$ & SD & $\mathrm{x}$ & SD \\
\hline Body weight & $1278.0_{a}^{a}$ & 13.03 & $1246.0_{\mathrm{a}, \mathrm{b}}$ & 48.27 & $1308.0_{a}$ & 38.34 & $1208.0_{a}, \mathrm{~b}$ & 84.97 & $1150.0 \mathrm{~b}$ & 76.48 & $1164.0 \mathrm{~b}$ & 68.04 & $1146.0 \mathrm{~b}$ & 49.79 \\
\hline $\begin{array}{c}\text { Body weight } \\
\text { after } \\
\text { decapitation of } \\
\text { the head }\end{array}$ & 1220.0 & 21.21 & $1145.0 \mathrm{a}, \mathrm{b}$ & 66.70 & 1226.6 & 41.30 & $1125.4 a, b$ & 81.47 & $1067.6 \mathrm{~b}$ & 75.10 & $1073.4 \mathrm{~b}$ & 79.93 & $1061.4 \mathrm{~b}$ & 44.68 \\
\hline $\begin{array}{c}\text { Body weight } \\
\text { after plucking }\end{array}$ & $1066.0 \mathrm{a}$ & 16.73 & $1082.6 \mathrm{a}$ & 71.76 & $1104.0_{a}$ & 56.83 & $1002.8 \mathrm{a}, \mathrm{b}$ & 86.05 & $955.2 \mathrm{~b}$ & 66.19 & $938.8 \mathrm{~b}$ & 71.98 & $919.2 \mathrm{~b}$ & 42.97 \\
\hline $\begin{array}{l}\text { Weight of the } \\
\text { carcass after } \\
\text { evisceration }\end{array}$ & $806.0 \mathrm{a}, \mathrm{c}$ & 15.16 & $849.2 \mathrm{a}$ & 45.72 & $841.0 \mathrm{a}$ & 21.41 & $784.2 \mathrm{a}, \mathrm{b}$ & 81.65 & $752.4 \mathrm{~b}, \mathrm{c}$ & 53.29 & $755.0 \mathrm{a}, \mathrm{b}$ & 45.13 & $713.8 \mathrm{~b}$ & 22.67 \\
\hline
\end{tabular}

a, b, c - means denoted by the same letter between individual study periods do not differ statistically significantly $(\mathrm{p} \leq 0.05)$

In the analyzed period, slaughter performance was at an average level of $64.5 \%$ with a differentiation from 60.4 to $69.1 \%$ in individual study periods. In terms of body weight, the heart was $1.0 \%$, the liver $2.1 \%$ and the muscle stomach $2.9 \%$. The remaining part (29\%) were inedible guts (Figure 2). A statistically significant relationship between the mass of internal organs (heart, liver, stomach) and the body weight of birds was shown (Table 2). The relationship between the mass of organs described and the carcass weight was significant only for the heart and stomach.

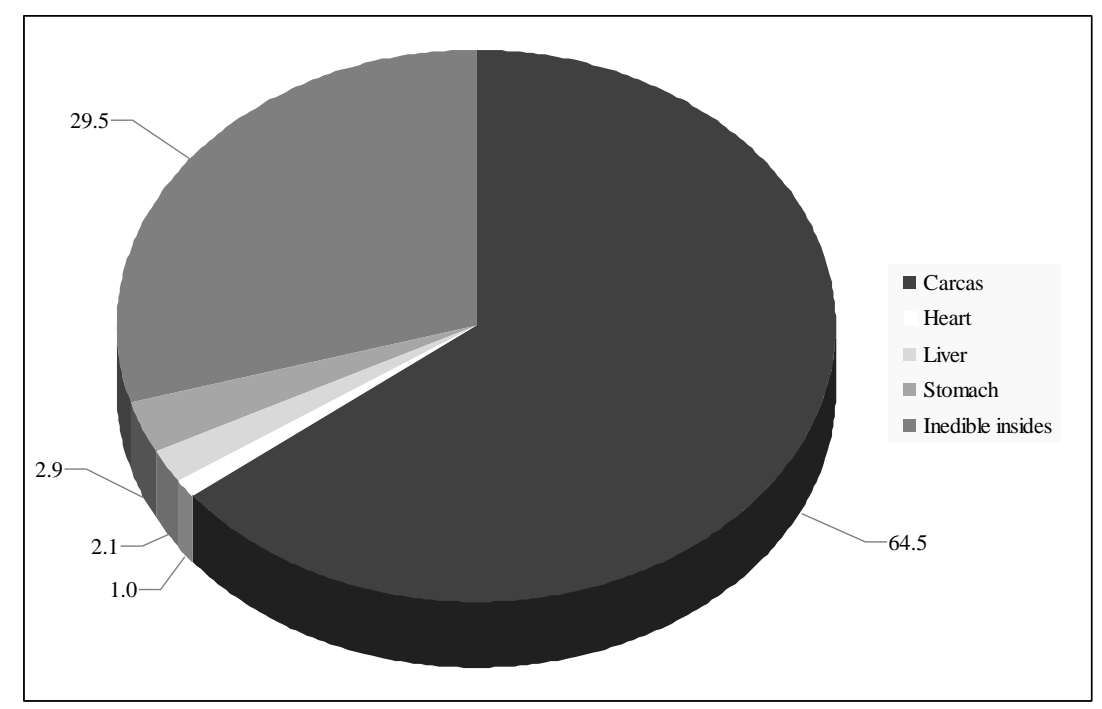

Figure 2. Percentage shares of carcass components in the total body weight male mallard

The chemical composition of the pectoral muscle showed slight variation in individual periods of the study (Table 3). Muscles contained 23.54 to $23.58 \%$ protein. The fat content showed a downward trend from 0.84 to $0.65 \%$ but these differences were not statistically significant $(\mathrm{p}>0.05)$. The highest heart weight $(12.6 \mathrm{~g})$ was found 
in drakes obtained in October. In the following months, until February, the mass of this body decreased, but in the last two study periods it increased to 11.8 grams in the last study period. The mean values of individual components of the breast muscle chemical composition did not differ statistically significantly between the study periods $(p>0.05)$. In contrast, the average values of the mass of internal organs showed differentiation between some periods of the study and some differences proved to be statistically significant $(\mathrm{p} \leq 0.05)$. During the seven-month study period, liver mass showed quite significant variations. The drakes shot in December had the highest average weight of this organ, while the lightest livers were found in drakes obtained in April. The average values of this trait between some periods of research were statistically significantly different $(\mathrm{p} \leq 0.05)$. Ducks from the first study period had the highest and statistically significantly different $(\mathrm{p} \leq 0.05)$ muscle mass.

Table 2. Correlation coefficients between body weight and carcass weight and weight of edible guts (offal)

\begin{tabular}{c|c|c|c}
\hline \multirow{2}{*}{ Item } & \multicolumn{3}{|c}{ Type of guts (offal) } \\
\cline { 2 - 4 } & Heart weight & Liver weight & Stomach weight \\
\hline Body weight & $0.459^{*}$ & $0.381^{*}$ & $0.465^{*}$ \\
\hline Carcass weight & $0.363^{*}$ & 0.212 & $0.343^{*}$ \\
\hline
\end{tabular}

*- significant correlations at $\mathrm{p} \leq 0.05$

Table 3. Chemical composition of mallard meat and mass of internal organs

\begin{tabular}{c|c|c|c|c|c|c|c}
\hline \multirow{2}{*}{ Item } & \multicolumn{7}{|c}{ Period research } \\
\cline { 2 - 7 } & I & II & III & IV & V & VI & VII \\
\hline Water, \% & 74.13 & 74.15 & 74.20 & 74.22 & 74.23 & 74.23 & 74.25 \\
Total protein, \% & 23.58 & 23.57 & 23.56 & 23.56 & 23.54 & 23.55 & 23.54 \\
Crude fat, \% & 0.84 & 0.85 & 0.83 & 0.79 & 0.77 & 0.73 & 0.65 \\
Crude ash, \% & 1.36 & 1.43 & 1.41 & 1.43 & 1.46 & 1.49 & 1.56 \\
Heart, g & $12.6_{\mathrm{a}}$ & $11.8_{\mathrm{a}}$ & $12.2_{\mathrm{a}}$ & $10.4_{\mathrm{a}, \mathrm{b}}$ & $10.0_{\mathrm{b}}$ & $11.6_{\mathrm{a}}$ & $11.8_{\mathrm{a}}$ \\
Liver, g & $26.6_{\mathrm{a}, \mathrm{b}}$ & $25.4_{\mathrm{a}, \mathrm{b}}$ & $29.2_{\mathrm{a}}$ & $23.0_{\mathrm{b}, \mathrm{c}}$ & $24.2_{\mathrm{a}, \mathrm{b}}$ & $25.4_{\mathrm{a}, \mathrm{b}}$ & $21.0_{\mathrm{c}}$ \\
Stomach, g & $60.8_{\mathrm{a}}$ & $37,0_{\mathrm{b}}$ & $33.4_{\mathrm{b}}$ & $34.8_{\mathrm{b}}$ & $35.8_{\mathrm{b}}$ & $26.6_{\mathrm{c}}$ & $24.4_{\mathrm{c}}$ \\
\hline
\end{tabular}

a, b, c - means denoted by the same letter between individual study periods do not differ statistically significantly $(\mathrm{p} \leq 0.05)$

In the next four periods, the mass was similar, while in the last two it dropped to an average level of 25.5 grams and these values differed significantly $(\mathrm{p} \leq 0.05)$ from the average for this feature from all other periods.

Analysis of the fatty acid profile indicates that the pectoral muscles of the crosses had an average of $38.28 \%$ content of saturated SFA fatty acids (Table 4). There were no significant differences during the study period. The share of MUFA monounsaturated acids was $17.24 \%$, and polyunsaturated at the average level of $40.35 \%$. In both cases, no significant differences were found between study periods $(p \leq 0.05)$. The share of unsaturated acids in total accounted for over $57 \%$, while their ratio to saturated acids was at the level of 1.5. On the other hand, the ratio of omega 6 to omega 3 polyunsaturated acids was not very differentiated in particular periods of the study and averaged 4.40 . 
Table 4. Profile of fatty acids [\%] of breast muscle fat of the mallards

\begin{tabular}{|c|c|c|c|c|c|c|c|c|}
\hline \multirow{2}{*}{ Specification } & \multicolumn{7}{|c|}{ Period research } & \multirow{2}{*}{ Mean } \\
\hline & $\mathrm{I}$ & II & III & IV & $\mathrm{V}$ & VI & VII & \\
\hline Lauric acid C 12:0 & 0.13 & 0.12 & 0.11 & 0.12 & 0.13 & 0.14 & 0.12 & 0.12 \\
\hline Myristic acid C 14:0 & 0.57 & 0.58 & 0.55 & 0.54 & 0.54 & 0.56 & 0.55 & 0.56 \\
\hline Palmitic acid C 16:0 & 20.28 & 20.25 & 20.27 & 20.30 & 20.29 & 20.30 & 20.28 & 20.28 \\
\hline $\begin{array}{c}\text { Pahnitoleic acid C } \\
16: 1\end{array}$ & 2.38 & 2.38 & 2.41 & 2.44 & 2.43 & 2.41 & 2.44 & 2.41 \\
\hline $\begin{array}{c}\text { Margaric acid C } \\
17: 0\end{array}$ & 0.86 & 0.84 & 0.89 & 0.95 & 0.99 & 0.91 & 0.93 & 0.91 \\
\hline $\begin{array}{c}\text { Margaroleic acid C } \\
17: 1\end{array}$ & 0.58 & 0.60 & 0.62 & 0.61 & 0.59 & 0.58 & 0.59 & 0.60 \\
\hline Stearic acid C 18:0 & 15.62 & 15.65 & 16.21 & 16.05 & 15.92 & 16.09 & 15.86 & 15.91 \\
\hline Oleic acid C 18:1 & 13.90 & 14.05 & 14.09 & 14.11 & 14.08 & 14.05 & 14.10 & 14.05 \\
\hline Linoleic acid C 18:2 & 19.27 & 19.43 & 19.38 & 19.54 & 19.41 & 19.44 & 19.53 & 19.43 \\
\hline $\begin{array}{c}\alpha \text {-linoleic acid C } \\
18: 3\end{array}$ & 7.35 & 7.39 & 7.41 & 7.44 & 7.41 & 7.39 & 7.40 & 7.40 \\
\hline $\begin{array}{c}\text { Arachidic acid C } \\
20: 0\end{array}$ & 0.49 & 0.48 & 0.51 & 0.50 & 0.51 & 0.53 & 0.47 & 0.50 \\
\hline $\begin{array}{c}\text { Gadoleic acid C } \\
20: 1\end{array}$ & 0.16 & 0.18 & 0.17 & 0.19 & 0.20 & 0.17 & 0.18 & 0.18 \\
\hline $\begin{array}{c}\text { Eicosadienoic acid } \\
\text { C } 20: 2\end{array}$ & 0.39 & 0.40 & 0.42 & 0.39 & 0.41 & 0.40 & 0.41 & 0.40 \\
\hline $\begin{array}{c}\text { Arachidonic acid C } \\
20: 4\end{array}$ & 13.19 & 13.14 & 13.11 & 13.12 & 13.08 & 13.07 & 13.11 & 13.12 \\
\hline Other acids & 4.83 & 4.51 & 3.85 & 3.70 & 4.01 & 3.96 & 4.03 & 4.13 \\
\hline SFA & 37.95 & 37.92 & 38.54 & 38.46 & 38.38 & 38.53 & 38.21 & 38.28 \\
\hline MUFA & 17.02 & 17.21 & 17.29 & 17.35 & 17.30 & 17.21 & 17.31 & 17.24 \\
\hline PUFA & 40.20 & 40.36 & 40.32 & 40.49 & 40.31 & 40.30 & 40.50 & 40.50 \\
\hline $\begin{array}{l}\text { UFA (MUFA + } \\
\text { PUFA) }\end{array}$ & 57.22 & 57.57 & 57.61 & 57.84 & 57.61 & 57.51 & 57.76 & 57.59 \\
\hline UFA/SFA & 1.51 & 1.52 & 1.49 & 1.50 & 1.50 & 1.49 & 1.51 & 1.50 \\
\hline PUFA $n-3$ & 7.35 & 7.39 & 7.41 & 7.44 & 7.41 & 7.39 & 7.40 & 7.40 \\
\hline PUFA $n-6$ & 32.46 & 32.57 & 32.49 & 32.66 & 32.49 & 32.51 & 32.64 & 32.55 \\
\hline$n-6 / n-3$ & 4.42 & 4.41 & 4.38 & 4.39 & 4.38 & 4.40 & 4.41 & 4.40 \\
\hline
\end{tabular}

\section{Organoleptic and bacteriological analysis}

The organoleptic analyzes carried out showed the presence of four drakees in the breast muscles of Sarcocystis protozoan cysts (Table 5). One case occurred in a drake shot in November, another case was shot in March, and two cases were found in drake obtained in April. In the case of one drake, the invasion was defined as very numerous (Figure 3), while in the remaining three cases the occurrence was less numerous.

Bacteriological analyzes of internal organs showed the presence of three groups of bacteria. Escherichia coli were found to be abundant in three drakes in the stomach and liver. They were specimens obtained in February and March, in the same complex of water reservoirs. One drake obtained in December and one in January found numerous occurrences of Aeromonas veronii. In one case, the bacterium was found in all internal organs, while in the other only in the liver. Staphylococcus aureus has also been found to be quite abundant in the livers of two drakes. In the small intestines of the individuals examined both organoleptically and using a stereoscopic microscope, tapeworms from the Hymenolepididae family were found. These parasites were found in all drakes with varying degrees of severity, from a few to several animals. 
Table 5. Results of macroscopics and bacteriological evaluation

\begin{tabular}{|c|c|c|c|c|c|c|c|c|}
\hline \multirow{2}{*}{\multicolumn{2}{|c|}{ Rated element }} & \multicolumn{7}{|c|}{ Period research } \\
\hline & & I & II & III & IV & V & VI & VII \\
\hline \multirow{2}{*}{$\begin{array}{l}\text { Macroscopic and } \\
\text { microscopic } \\
\text { evaluation }\end{array}$} & Carcass & - & $\begin{array}{c}\text { Sarcocistosis } \\
1 \text { cases }\end{array}$ & - & - & - & $\begin{array}{l}\text { Sarcocistosis } \\
1 \text { case }\end{array}$ & $\begin{array}{l}\text { Sarcocistosis } \\
2 \text { cases }\end{array}$ \\
\hline & Intestines & $\begin{array}{c}\text { Tapeworms from the } \\
\begin{array}{c}\text { Hymenolepididae } \\
\text { family }\end{array}\end{array}$ & $\begin{array}{c}\text { Tapeworms from the } \\
\begin{array}{c}\text { Hymenolepididae } \\
\text { family }\end{array}\end{array}$ & $\begin{array}{c}\text { Tapeworms from the } \\
\text { Hymenolepididae } \\
\text { family }\end{array}$ & $\begin{array}{c}\text { Tapeworms from the } \\
\begin{array}{c}\text { Hymenolepididae } \\
\text { family }\end{array}\end{array}$ & $\begin{array}{c}\text { Tapeworms from the } \\
\begin{array}{c}\text { Hymenolepididae } \\
\text { family }\end{array}\end{array}$ & $\begin{array}{c}\text { Tapeworms from the } \\
\text { Hymenolepididae } \\
\text { family }\end{array}$ & $\begin{array}{c}\text { Tapeworms from the } \\
\begin{array}{c}\text { Hymenolepididae } \\
\text { family }\end{array}\end{array}$ \\
\hline \multirow{3}{*}{$\begin{array}{l}\text { Bacteriological } \\
\text { evaluation }\end{array}$} & Heart & - & - & $\begin{array}{c}\text { Aeromonas veronii } \\
1 \text { case }(++) \\
\end{array}$ & - & - & - & - \\
\hline & Liver & $\begin{array}{c}\text { Staphylococcus } \\
\text { aureus } \\
1 \text { case }(+) \\
\end{array}$ & - & $\begin{array}{c}\text { Aeromonas veronii } \\
1 \text { case }(++)\end{array}$ & $\begin{array}{c}\text { Aeromonas veronii } \\
1 \text { (case }(++)\end{array}$ & $\begin{array}{c}\text { Escherichia coli } \\
1 \text { case }(++)\end{array}$ & $\begin{array}{c}\text { Escherichia coli } \\
2 \text { cases }(++)\end{array}$ & $\begin{array}{c}\text { Staphylococcus } \\
\text { aureus } \\
1 \text { case }(+) \\
\end{array}$ \\
\hline & Stomach & - & - & $\begin{array}{c}\text { Aeromonas veronii } \\
1 \text { case }(++)\end{array}$ & - & $\begin{array}{c}\text { Escherichia coli } \\
1 \text { case }(++)\end{array}$ & $\begin{array}{l}\text { Escherichia coli } \\
2 \text { cases }(++)\end{array}$ & - \\
\hline
\end{tabular}




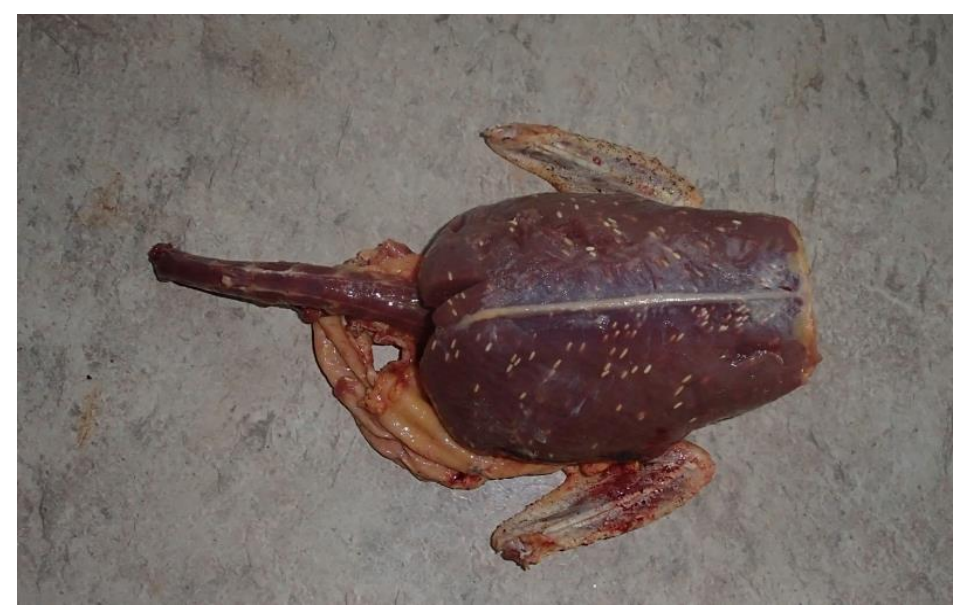

Figure 3. Numerous sarcocysts in the pectoral muscles of a male mallard duck

\section{Resistance to antibiotics}

As part of the study, an assessment of the sensitivity of isolated bacterial strains to antibiotics in vitro was performed (Table 6). The isolated Escherichia coli strain was found to be resistant to most of the antibiotics used, moderately sensitive to one and sensitive to Colistin and Doxicicline. The Aeromonas veronii strain was resistant to 4 antibiotics and sensitive to Colistin, Doxicicline and Enrofloxacine. In turn, the Staphylococcus aureus strain was also resistant to 4 of the antibiotics used, moderately sensitive to Enrofloxacine, and sensitive to Doxicicline and Lincomycin/Spectinomycin.

Table 6. Sensitivity of isolated bacterial strains to antibiotics

\begin{tabular}{c|c|c|c}
\hline \multirow{2}{*}{ Antibiotic used } & \multicolumn{3}{|c}{ Type of bacterial strain } \\
\cline { 2 - 4 } & Escherichia coli & Aeromonas veronii & $\begin{array}{c}\text { Staphylococcus } \\
\text { aureus }\end{array}$ \\
\hline Doxycycline DO30 & $\mathrm{W}$ & $\mathrm{W}$ & $\mathrm{W}$ \\
Amoxycilin AML25/AX25 & $\mathrm{O}$ & $\mathrm{O}$ & $\mathrm{O}$ \\
Ampicillin AMP10/AM10 & $\mathrm{O}$ & $\mathrm{O}$ & $\mathrm{O}$ \\
Amoxycillin/clavulanic acid Synulox AMC30 & $\mathrm{O}$ & $\mathrm{O}$ & $\mathrm{W}$ \\
Lincomycin/Spectinomycin LS109 & $\mathrm{O}$ & $\mathrm{O}$ & $\mathrm{S} W$ \\
Enrofloxacin ENR5 & $\mathrm{SW}$ & $\mathrm{W}$ & $\mathrm{O}$ \\
Colistin CT50 & $\mathrm{W}$ & $\mathrm{W}$ & \\
\hline
\end{tabular}

Description: W - sensitive; ŚW - moderately sensitive; O - resistant

\section{Spermatogenesis process}

The analysis of the spermatogenesis process was carried out based on the mass of the testicles and epididymis and the cytological evaluation of testicular and epididymal imprints. The analysis was carried out until the presence of correctly formed sperm was observed. During the seven-month period of research for the period from October to January, the testicular mass was quite stable and ranged from 0.205 to 0.414 grams (Figure 4). In duck shot in February, testis weight was $0.712 \mathrm{~g}$, and this value did not differ significantly from those of previous months. In drakes obtained in March, the average testis weight was 2,572 $\mathrm{g}$ and was significantly higher than the values obtained in previous months, and lower than the last test $(\mathrm{p} \leq 0.05)$. The average mass of drake 
testicles shot in April was $14.140 \mathrm{~g}$ and was significantly higher $(\mathrm{p} \leq 0.05)$ than the values obtained in all earlier months of the study. The correlation coefficient between body weight and testicular weight was negative and statistically insignificant, $r_{x y}=-$ 0.400 .

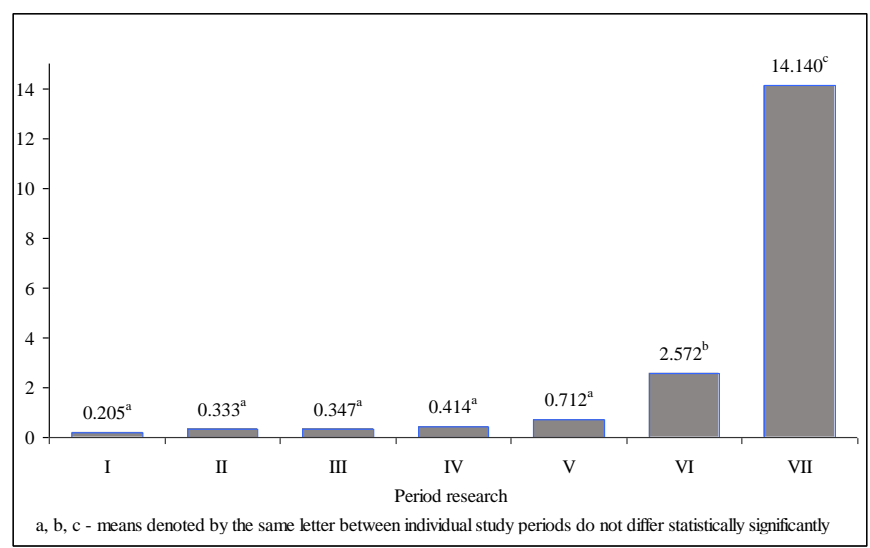

Figure 4. Shaping the weight of testes ( $g$ ) drakes during the study period

In the evaluated microscopic preparations, in the initial period of research, i.e. October, proper germ cells were not shown, but only sperm-forming epithelial cells difficult to identify, in the initial period of development presumably spermatogonies (Figure 5). Later, from November to the end of February, characteristic cells were observed in the preparations - oval with a wide, clear layer of cytoplasm and the nucleus in the central part of the cell, reminiscent of spermatocytes. It was observed that the shape of the cell changed from oval to round with time, and the shape of the nucleus from cylindrical to oval (Figure 6). From the first half of March, correctly formed spermatozoa were visible in the preparations, but spermatocytes were also visible (Figure 7). In addition, spermatides in the less advanced - early spermatid (WS) and the more advanced - late spermatid (PS) stage of transformation into mature germ cells spermatozoa were also seen in preparations from this period (Figure 8). Duck sperm had a very large head in the shape of an elongated cone and a thinly visible thin withe, reminiscent of hot pepper Peperoni (Figure 9).

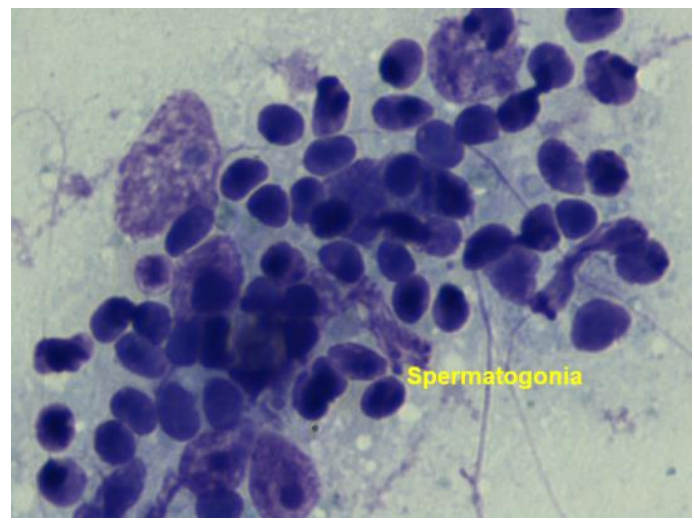

Figure 5. Cytological preparation, formed by impressing on a microscope slide, the epididymis and testis of the drake, made in October, visible germ cells in the initial period of development spermatogonia. Hemacolor staining (1000 x) 


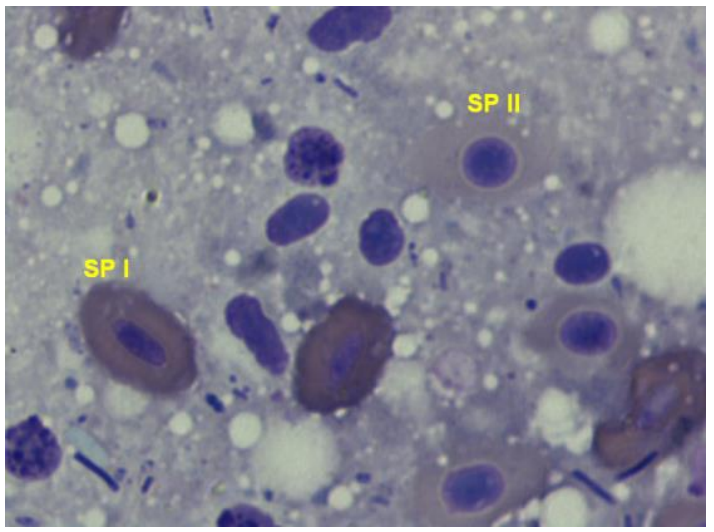

Figure 6. Cytological preparation, formed by impressing on a microscope slide, the epididymis and testis of the drake, made at the turn of November and December, visible germ cells of first order spermatocytes (SP I) and second order spermatocytes (SP II). Hemacolor staining

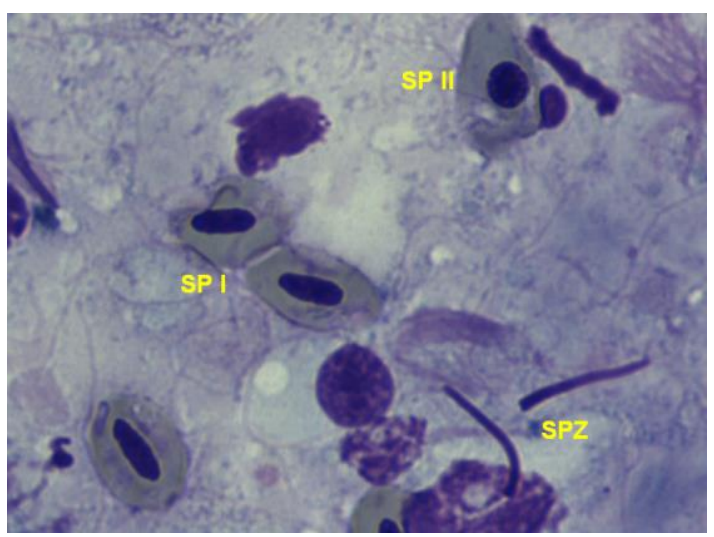

Figure 7. Cytological preparation, formed by impressing on a microscope slide, the epididymis and testis of the drake, made in the first half of March. Visible germ cells of first order spermatocytes (SP I), second order spermatocytes (SP II) and spermatozoa (SPZ). Hemacolor staining $(1000 x)$

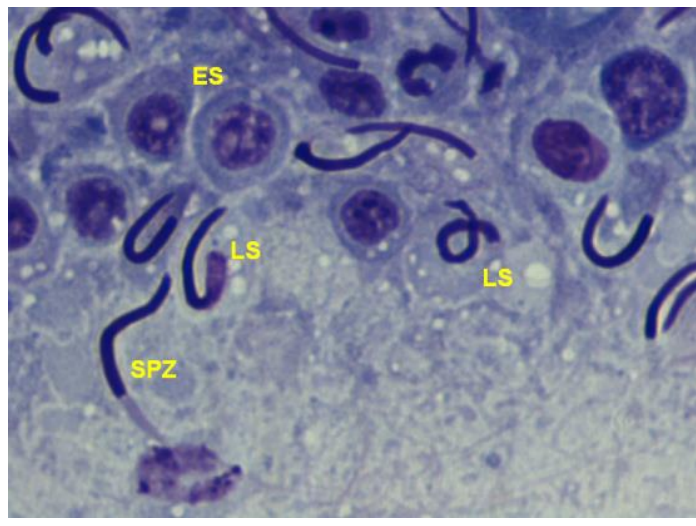

Figure 8. Cytological preparation, formed by impressing on a microscope slide, the epididymis and testis of the drake, made in the second half of March. Visible early spermatids (ES), late spermatids (LS) and spermatozoa (SPE). Hemacolor staining (1000 x) 


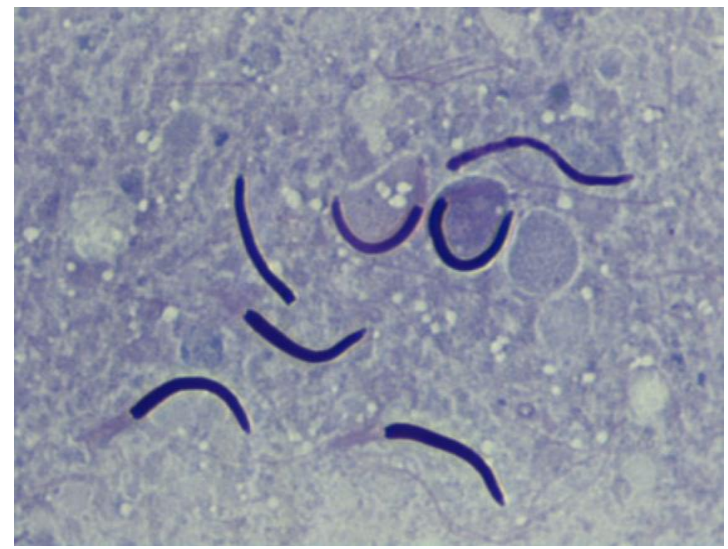

Figure 9. Cytological preparation, formed by impressing on a microscope slide, the epididymis and testis of the drake, made in the first half of April. Visible mature spermatozoa. Hemacolor staining $(1000 x)$

\section{Discussion}

The obtained weight results of mallard ducks, despite the differences in the 7-month research cycle, indicate that it was higher than that in studies conducted in north-eastern Poland, despite the fact that these studies covered the winter period and matings, which is associated with more than $10 \%$ decrease in body weight compared to the initial weight (Janiszewski et al., 2018). The average value of this trait is similar to that of research conducted in Hungary and in the case of males it is only less than 14 grams lower (Szász et al., 2006), while compared to the results of research from north-eastern France, it was 49 grams lower (Boos et al., 2002). The carcass weight was also higher than that in research conducted in north-eastern Poland, which resulted in slaughter efficiency higher by $7.7 \%$. On the other hand, the share of heart and liver weight was similar, and the stomach weight was significantly lower compared to ducks from north-eastern Poland (Janiszewski et al., 2018). Also the chemical composition of the carcass was similar to that of research conducted in north-eastern Poland, and slight differences were due to the date of hunting and the habitat from which the birds came. At the same time, the pectoral muscles were characterized by a high protein content, with a low fat content, whose share decreased with the time of shooting (Lorenzo et al., 2011; Janiszewski et al., 2018). In turn, the results of other authors indicate lower protein content and definitely higher fat in meat from mallard ducks (Cobos et al., 2000).

The content of 14 fatty acids was found in the pectoral muscles of male crosses. The occurrence of saturated fatty acids (SFA) as well as monounsaturated (MUFA) and polyunsaturated (PUFA) was similar to that of other authors. However, the content of individual acids showed slight variation, which may be due to the composition of the diet of birds from different environments and the date of their shooting (Cobos et al., 2000; Nuernberg et al., 2011; Janiszewski et al., 2018). Quite a high level of C 20 PUFA acids, especially C 20:4, was conditioned by the diet of birds, because these acids come only from exogenous sources and cannot be synthesized in the body of birds. High levels of these acids in mallard meat have also been confirmed in studies by other authors (Mishra et al., 1993; Nuernberg et al., 2011). Such a high level of PUFA acids, as well as the UFA to SFA ratio of 1.50 means that the meat of the crosses has enormous health benefits, 
especially for people suffering from hypertension, which has been confirmed in experimental and clinical studies (Appel et al., 1993).

The demonstrated occurrence of protozoan cysts of the Sarcocystis genus in 4 ducks, with varying severity, indicates that there is a fairly serious threat from this pathogen. Based on the data obtained, it can be assumed that every 5 ducks may have sarcocysts. Until now, reports of sarcocystosis in ducks have been few, which were explained by the fact that duck hunters did not pay attention especially to the rare sarcocysts (Stenzel and Koncicki, 2007; Śmiałek et al., 2014; Flis and Grela, 2018). Intestinal parasites, including those found in the Hymenolepididae family, are quite common in both wild and domestic ducks, and although they have a destabilizing effect on the host organism, they do not affect the meat's utility (Raś-Noryńska et al., 2016; Sokół et al., 2016). Studies conducted in three different places in Poland have shown the occurrence of 22 nematode species from the family Hymenolepididae (Nowak et al., 2012). Also Ukrainian studies indicate the presence of parasites of this family with varying severity (Syrota et al., 2018).

The finding in some internal organs of Escherichia coli indicates that the crossbreeds can be an important reservoir of zoonotic strains of this bacterium, as well as a bioindicator of the state of the environment, mainly of the water reservoirs in which they reside. This is confirmed by studies of other authors indicating that crosses can be an important source of $E$. coli strains capable of causing intestinal diseases (Ewers et al., 2009). Slovak studies have shown that in fresh meat of crosses no E. Coli bacteria were found, and they were found after a 7-day meat maturation period (Haščík et al., 2010). Gram negative rods of the genus Aeromonas are widespread in the aquatic environment, thus they are quite common in birds inhabiting these habitats. They may also be responsible for infection in humans (Mencacci et al., 2003). The finding of two cases of Staphylococcus aureus is a confirmation that this highly widespread bacterium can also occur in mallards, and thus may be a potential source of infection for people who have contact with hunted ducks as well as eating meat derived from them. In addition, duck droppings can also be a source of infection, as well as a vector of the spread of bacteria in the natural environment, and thus may pose a threat to public health (Adegunloye and Adejumo, 2014).

Our own research shows that reproductive processes in male mallard ducks are normal. Outside of the October and November breeding season, inhibition of sexual activity in drakes was observed. This is evidenced by both the very low testicular mass and the presence in the cytological preparations of the testicles from this period, only the basic germ cells - spermatogonia. Although the ducks are already mating at this time of year, the spermatogenesis process is still stopped. Bonding of both sexes in pairs is dictated, as Davis studies (2002) show, by a periodic increase in testosterone levels in drakes. After pairing, the level of this hormone decreases, and during the reproductive period it gradually increases again and also gradually stimulates the process of spermatogenesis. A slight increase in testosterone levels causes mating of ducks and mating behavior, but it is too low to activate spermatogenesis. That is why, in the initial studies, no increase in testicular mass and germ cell development was demonstrated. Similar relationships were observed in guinea fowls (Numida meleagris), which also show seasonal reproduction (Abdul-Rahman et al., 2016). In the following months of December, January and February, the spermatogenesis process, which was already beginning, was observed, since the first and second order spermatocytes and second order spermatocytes were visible in the preparations. Although the testicular mass was still low, it increased steadily (from October to February it increased more than threefold). Similar increase in testicular 
weight and development of reproductive cells in the beginning reproductive season was demonstrated by other authors in drakes and pheasants (Bauchinger et al., 2007; Górska et al., 2015). In March, the process of spermatogenesis was already developed; fully developed spermatozoa appeared in cytological preparations. However, it seems that the drakes obtained full fertility at the beginning of April, which is visible both in the highest testis mass obtained (increase 69 times since the beginning of the study) and the presence of a large number of spermatozoa in cytological preparations. The proper intensification of the spermatogenesis process is a very important factor in the reproduction of ducks, but equally important is the shift associated with global warming during the breeding period in wild birds (Virkkala and Lehikoinen, 2017). Research carried out on the capercaillie and the black grouse has shown acceleration of the breeding period, but for the benefit of reproduction rates in these bird species (Wegge and Rolstad, 2017). It is not known, however, whether this effect can also be expected in ducks.

\section{Conclusions}

The conducted research authorizes to formulate the following statements and conclusions:

Body weight and cross carcass weight were similar to the results of other authors, and its $10 \%$ decrease occurred only in the winter and spring months, which should be associated with the climatic conditions and course of mating in this species. The crosswords were characterized by high slaughter efficiency at the level of $64.5 \%$. A statistically significant relationship between the mass of internal organs (heart, liver, stomach) and the body weight of birds was demonstrated.

The chemical composition of cross carcasses was characterized by high protein content and low fat content. At the same time, the fatty acid profile indicates a high content of unsaturated fatty acids, including those from the C 20 group, which can only come from exogenous sources. The high content of the described acids in connection with the favorable ratio of UFA to SFA at 1.5, confirms the high health benefits of these birds, which should be an important component of the diet, especially for people with hypertension.

Organoleptic and bacteriological evaluation of carcasses showed the occurrence of protozoan cysts of the Sarcocystis genus and intestinal parasites of the Hymenolepididae family. These groups of parasites, despite having an impact on the host, do not play a major epidemiological significance. At the same time, it should be emphasized that the presence of E. coli and Staphylococcus aureus in some internal organs is of some concern, especially since these bacteria showed sensitivity to only two of the seven antibiotics used. This is due to the fact that crosswords can be a potential source of human infection as well as a reservoir, and also a vector for the spread of these bacteria, and thus pose a threat to public health.

Assessment of both testicular weight and cytological imprints made of testicles and epididymis allows confirmation of the correct development of the spermatogenesis process in mallard ducks during the breeding season. Despite the fact that pairing takes place already in winter, the fullness of matings, and thus the fertilization of females, takes place in April, which is confirmed by the results obtained. However, it is not possible to determine from conducted studies whether there were shifts during the breeding season, this requires furthermore focused research. 
Funding. This research received no external funding.

Conflicts of Interests. The authors declare no conflict of interests.

\section{REFERENCES}

[1] Abdul-Rahman, I. I., Robinson, J. E., Obese, F. Y., Jeffcoate, I. A., Awumbila, B. (2016): Effects of season on the reproductive organ and plasma testosterone concentrations in guinea cocks (Numida meleagris). - Poultry Science 95: 636-644. doi.org/10.3382/ps/pev342.

[2] Adegunloye, D. V., Adejumo, F. A. (2014): Microbial assessment of Turkey (Meleagris ocellata L.) and Duck (Anas platyrhynchos L.) Faeces (Droppings) in Akure Metropolis. - Advances Microbiology 4: 774-779. doi.org/10.4236/aim.2014.412085.

[3] Appel, L. J., Miller, E. R., Seidler, A. J., Whelton, P. K. (1993): Does supplementation of diet with ,fish oil" reduce blood pressure? A meta-analysis of controlled clinical trial. Archives Internal Medicine 153: 1429-1438.

[4] Bauchinger, U., Van't Hof, T., Biebach, H. (2007): Testicular development during longdistance spring migration. - Hormones Behavior 51: 295-305.

[5] Bertolinii, R., Zgrablic, G., Cuffolo, E. (2005): Wild game meat: Products, market, legislation and processing controls. - Veterinary Research Communication 29(2): 97-100.

[6] Betlejewska, K., Kalisińska, E., Kornyushin, V., Salamatin, R. (2002): Eucoleus contours (Creplin, 1839) nematode in mallard (Anas platyrhynchos Linnaeus, 1758) from NorthWestern Poland. - Electronic Journal Polish Agricultural Universities - Veterinary Medicine 5: 03.

[7] Biesiada-Drzazga, B., Socha, S., Janocha, A., Banaszkiewicz, T., Koncerewicz, A. (2011): Assessment of slaughter value and quality of meat in common game pheasants (Phasianus colchicus). - Żywność Nauka Technologia Jakość 1: 79-86.

[8] Boos, M., Zorn, T., Le Maho, Y., Groscolas, R., Robin, J. P. (2002): Sex differences in body composition of wintering Mallards (Anas platyrhynchos): possible implications for survival and reproductive. - Bird Study 49: 212-218.

[9] Borman, M., Mattsson, L. (2012): The hunting value of game in Sweden: Have changes occurred over recent decades? - Scandinavian Journal Forest Research 27(7): 1-6.

[10] Borowska, D., Jabłoński, A., Pejsak, Z. (2014): Disk diffusion method in veterinary diagnostics - practical data. - Życie Weterynaryjne 89(2): 116-120.

[11] Cobos, A., Veiga, A., Díaz, O. (2000): Chemical and fatty acid composition of meat and liver of wild ducks (Anas platyrhynchos). - Food Chemistry 68(1): 77-79.

[12] Davis, E. S. (2002): Female choice and the benefits of mate guarding by male mallards. Animal Behaviour 64(4): 619-628.

[13] Dynowska, M., Meissner, W., Pacyńska, J. (2013): Mallard duck (Anas platyrhynchos) as a potential link in the epidemiological chain mycoses originating from water reservoirs. Bulletin Veterinary Institute Pulawy 57(3): 323-328.

[14] Ewers, C., Guenther, S., Wieler, L. H., Schierack, P. (2009): Mallard duck - a waterfowl species with high risk of distributing Escherichia coli pathogenic for humans. Environmental Microbiology Reports 1(6): 510-517. doi:10.1111/j.1758-2229.2009.00058.x.

[15] Flis, M., Magdziak, K., Rataj, B. (2017): Social and economic determinants meat of game animals consumption. - Przegląd Leśniczy 8(314/XXVII): 12-14.

[16] Flis, M., Grela, E. R. (2018): Sarcocystosis in a male of the Mallard Anas platyrhynchos. - Ornis Polonica 59: 81-87.

[17] Flis, M., Grela, E. R., Gugała, D., Kołodziejski, A. (2019): Carcass composition and fatty acid profile of pectoral muscle of male and female pheasants (Phasianus colchicus). Żywność Nauka Technologia Jakość 26(1): 111-124. 
[18] Folch, J., Less, M., Stanley, G. H. (1957): A simple method for the isolation and purification of total lipids from animal tissues. - Journal Biological Chemistry 226(1): 497-509.

[19] Gaston, A. J., Gilchrist, H. G., Mallory, M. L., Smith, P. A. (2009): Changes in seasonal events, peak food availability, and consequent breeding adjustment in a marine bird: a case of progressive mismatching. - Condor 111: 111-119.

[20] Górecka, J., Szmańko, T. (2010): Nutritional values of venison (Original in Polish: Walory żywieniowe dziczyzny). - Magazyn Przemysłu Mięsnego 1-2: 20-21.

[21] Górska, M., Wojciechowska, J., Wojtysiak, D. (2015): Seasonal changesin steroidogenic activity and pheasant testicular microstructure (Original in Polish: Sezonowe zmiany w aktywności steroidogennej oraz mikrostrukturze jąder bażanta). - Roczniki Naukowe Zootechniki 42(2): 147-154.

[22] Guillemain, M., Elmberg, J., Gauthier-Clerc, M., Massez, G., Hearn, R., Champagnon, J., Simon, G. (2010): Wintering French Mallard and Teal are heavier and in better body condition than 30 years ago: Effects of a changing environment? - Ambio 39(2): 170180.

[23] Guillemain, M., Pöysä, H., Fox, A. D., Arzel, C., Dessborn, L., Ekroos, J., Gunnarsson, G., Holm, T. E., Christensen, T. K., Lehikoinen, A., Mitchel, C., Rintala, J., Møller, A. P. (2013): Effect of climate change on European dicks: what do we know and what do we need to know? - Wildlife Biology 19: 404-419.

[24] Gunnarsson, G., Latorre-Margalef, N., Hobson, K. A., Van Wilgenburg, S. L., Almberg, J., Olsen, B., Fouchier, R. A. M., Waldenström, J. (2012): Disease dynamics and bird migration - linking mallards Anas platyrhynchos and subtype diversity of the influenza A virus in time and space. - PLoS One 7(4): e35679. doi:10.1371/journal.pone.0035679.

[25] Haščík, P., Nováková, I., Kačániová, M., Fikselová, M., Kuwová, S. (2010): Microbiological quality of the Anas platyrhynchos and the Fulica atra meat. - Ecological Chemistry Engineering A 17(1): 81-87.

[26] Hoffman, L. C., Wiklund, E. (2006): Game and venison - Meat for the modern consumer. - Meat Science 74(1): 197-208.

[27] Janiszewski, P., Murawska, D., Hanzal, V., Gesek, M., Michalik, D., Zawadka, M. (2018): Carcass characteristics, meat quality, and fatty acid composition of wild-living mallards (Anas platyrhynchos L.). - Poultry Science 97(2): 709-715.

[28] Kasprzyk, A. (2013): Meat in the human diet - history, present and future (Original in Polish: Mięso w diecie człowieka - historia, teraźniejszość i przyszłość). - Produkcja zwierzęca w warunkach zrównoważonego rolnictwa. Materiały LXXVIII Zjazdu Naukowego Polskiego Towarzystwa Zootechnicznego, Kraków: 133-145.

[29] Kokoszyński, D., Bernacki, Z., Pieczewski, W. (2014): Carcass composition and quality of meat from game pheasants (P. colchicus) depending on age and sex. - Europ. Poultry Science 78. DOI: 10.1399/eps.2014.16.

[30] Książkiewicz, J. (2006): A mallard duck - Anas platyrhynchos L. means a flat-billed duck. - Wiadomości Zootechniczne 1: 25-30.

[31] Kuźniacka, J., Adamski, M., Bernacki, Z. (2007): Effect of age and sex of pheasants (Phasianus colchicus L.) on selected physical properties and chemical composition of meat. - Annals Animals Science 1(7): 45-53.

[32] Kwiecińska, K., Kosicka-Gębska, M., Gębski, J. (2016): Assessment of consumer preferences related to game selection (Original in Polish: Ocena preferencji konsumentów związanych z wyborem dziczyzny). - Handel Wewnetrzny 1: 53-64.

[33] List of hunting reporting data 2018. (2019): Zestawienie danych sprawozdawczości łowieckiej 2018 rok (in Polish). - Stacja Badawcza Polskiego Związku Łowieckiego w Czempiniu, Biuletyn Czempiń.

[34] Ljung, P. E., Riley, S. J., Ericsson, G. (2015): Game meat consumption feeds urban support of traditional use of natural resources. - Journal Society Natural Resources 28(6): 657-669. 
[35] Lorenzo, J. M., Purrinos, L., Temperan, S., Bermudez, R., Tallon, S., Franco, D. (2011): Physicochemical and nutritional composition of dry-cured duck breast. - Poultry Science 90(4): 931-940.

[36] Mencacci, A., Cenci, E., Mazzolla, R., Farinelli, S., D`Alò, F., Vitali, M., Bistoni, F. (2003): Aeromonas veronii biovar veronii septicaemia and acute suppurative cholangitis in a patient with hepatitis B. - Journal Medical Microbiologu 52(8): 727-730.

[37] Mishra, V. K., Temelli, F., Ooraikul, B. (1993): Extraction and purication of $\omega-3$ fatty acids with an emphasis on supercritical fluid extraction - A review. - Food Research International 26(3): 217-226.

[38] Nagalska, H. M., Rejman, K. (2014): Consumer knowledge of venison and purchasing behavior on the meat market (Original in Polish: Wiedza konsumentów o dziczyźnie $\mathrm{i}$ zachowania nabywcze na rynku tego mięsa). - Marketing i Rynek 6: 488-500.

[39] Nowak, M., Kavetska, K., Królaczyk, K., Stapf, A., Korna, S., Wajdzik, M., Basiaga, M. (2012): Comparative study of Cestode and Nematode fauna of the gastrointestinal tract of mallard (Anas platyrhynchos L. 1758) from three different Polish ecosystem. - Acta Scientiarum Polonorum Zootechnica 11(4): 99-106.

[40] Nuernberg, K., Slamecka, J., Mojto, J., Gasparik, J., Nuernberg, G. (2011): Muscle fat composition of pheasants (Phasianus colchicus), wild ducks (Anas platyrhynchos) and black coots (Fulica atra). - European Journal Wildlife Research 57(4): 795-803.

[41] Popczyk, B. (2012): Game trading problems (Original in Polish: Problemy handlu dziczyzną). - In: Gwiazdowicz, D. J. (ed.) Problemy współczesnego łowiectwa w Polsce.. Polskie Towarzystwo Leśne. Regionalna Dyrekcja Lasów Państwowych w Poznaniu. Poznań: 137-150.

[42] Raś-Noryńska, M., Sokół, R., Michalczyk, M., Koziatek-Sadłowska, S. (2016): Parasites of the captive mallard duck (Anas platyrhynchos). - Annals Parasitology 62(128).

[43] Siminska, E., Bernacka, H., Sadowski, T. (2011): The global and domestic venison market situation. - Annals Warsaw University Life Science - SGGW Animal Science 50: 89-96.

[44] Smith, D. B., Rohwer, F. C. (1997): Perceptions of releases of captive-read mallards with emphasis on an intensive program in Maryland. - In: Proceedings of the Transactions of the North American Wildlife and Natural Resources Conference 62: 403-411.

[45] Sokół, R., Raś-Noryńska, M. A., Gesek, M. A., Murawska, D., Hanzal, V., Janiszewski, P. E. (2016): The parasites of the mallard duck (Anas platyrhynchos) as an indicator of health status and quality of the environment. - Annals Parasitology 62(4): 351-353.

[46] Söderquist, P. (2012): Ecological and genetic consequences of introductions of native species: The mallard as a model system. - Introductory Research Essay No. 15 Department of Wildlife, Fish, and Environmental Studies Swedish University of Agricultural Sciences 90183 Umeå, Sweden.

[47] Stenzel, T., Koncicki, A. (2007): A case of sarcocystosis in wild duck. - Medycyna Weterynaryjna 63(11): 1361-1362.

[48] Syrota, Y. Y., Greben, O. B., Poluda, A. M., Maleha, O. M., Lisitsyna, O. I., Kornyushin, V. V. (2018): Helminths of the mallard, Anas platyrhynchos (Aves, Anatidae), in Ukraine: Analysis of the diversity in mixed forest zone and the Black Sea region. - UDC 595.1:598.252.1: 267-278.

[49] Szász, S., Sugár, L., Pőcz, O., Ujvári, J., Taraszenkó, Z. (2006): Some slaughter characteristics of the mallard (Anas p. platyrhynchos L. 1758). - Acta Agraria Kaposváriensis 10(2): 321-323.

[50] Śmiałek, M., Stenzel, T., Śmiałek, A., Koncicki, A. (2014): Clinical casas of sarcocystosis in duck. - Życie Weterynaryjne 89(7): 594-596.

[51] Tracey, J., Lukins, B., Haselden, C. (2008): Lord Howe Island Duck: Abundance, Impact and Management Options. - A report to the World Heritage Unit. Lord Howe Island Board. Invasive Animals Cooperative Research Centre, Canberra: 1-35. 
[52] Virkkala, R., Lehikoinen, A. (2017): Birds on the move in the face of climate change: High species turnover in northern Europe. - Ecology Evolution 7(20): 8201-8209. doi: $10.1002 /$ ece 3.3328 .

[53] Wegge, P., Rolstad, J. (2017): Climate change and bird reproduction: warmer springs benefit breeding success in boreal forest grouse. - Procedings Biological Sciences 284(1866). pii: 20171528. doi: 10.1098/rspb.2017.1528.

[54] Wille, M., Bröjer, C., Lundkvist, A., Järhult, J. D. (2018): Alternate routes of influenza A virus infection in mallard (Anas platyrhynchos). - Veterinary Research 49(110): doi.org/10.1186/s13567-018-0604-0.

[55] Żbikowski, A., Szeleszczuk, P., Karpińska, E., Rzewulska, M., Malicka, E., Biniek, M. (2006): Epidemic deaths of mallard ducks after Aeromonas hydrophila infection. Medycyna Weterynaryjna 62(6): 720-722.

[56] Żmijewski, T., Mozolewski, W., Rybaczek, S. (2018): Characteristics and directions of wild game meat usage. - Przemysł Spożywczy 72(3): 32-35. 